The Canadian Mineralogist

Vol. 39, pp. 57-71 (2001)

\title{
MICRO-ANALYTICAL STUDY OF THE OPTICAL PROPERTIES OF RAINBOW AND SHEEN OBSIDIANS
}

\author{
CHI MA \\ Division of Geological and Planetary Sciences, California Institute of Technology, Pasadena, California 91125, U.S.A. \\ JENNIFER GRESH ${ }^{\S}$ \\ Department of Geology, Temple University, Philadelphia, Pennsylvania 19122, U.S.A. \\ GEORGE R. ROSSMAN \\ Division of Geological and Planetary Sciences, California Institute of Technology, Pasadena, California 91125, U.S.A. \\ GENE C. ULMER \\ Department of Geology, Temple University, Philadelphia, Pennsylvania 19122, U.S.A. \\ EDWARD P. VICENZIII \\ Princeton Materials Institute, Princeton University, Princeton, New Jersey 08540, U.S.A.
}

\begin{abstract}
Samples of Mexican obsidian that exhibit either "sheen" or "rainbow" optical properties were examined with a combination of EMP, SEM, TEM, as well as visible and IR spectroscopy. Electron-microprobe analyses of the sheen matrix give (in wt.\%): $76.2 \mathrm{SiO}_{2}, 0.2 \mathrm{TiO}_{2}, 11.6 \mathrm{Al}_{2} \mathrm{O}_{3}, 2.2 \mathrm{FeO}_{\mathrm{TOT}}, 0.07 \mathrm{MgO}, 0.1 \mathrm{CaO}, 4.8 \mathrm{Na}_{2} \mathrm{O}$ and $4.4 \mathrm{~K}_{2} \mathrm{O}$. The sheen is attributed to the presence of aligned flow-stretched hollow vesicles in the gemological literature. SEM images show that many of the flow-aligned lenticular areas are a second rhyolite glass with, on average, $74.6 \mathrm{SiO}_{2}, 0.2 \mathrm{TiO}_{2}, 12.7 \mathrm{Al}_{2} \mathrm{O}_{3}, 2.1 \mathrm{FeO}_{\mathrm{TOT}}, 0.1 \mathrm{MgO}, 0.9 \mathrm{CaO}, 5.6 \mathrm{Na}_{2} \mathrm{O}$ and $4.6 \mathrm{~K}_{2} \mathrm{O}$. These two compositions do not overlap at the $2 \sigma$ level. Their inferred indices of refraction differ by as much as 0.04 , leading to optical interference along the elliptical interfaces of the two glasses. Thus we postulate that the sheen reflects differences in indices of refraction $(\eta)$ between the matrix obsidian and the lower $\eta$ of either gas-filled or glass-filled vesicles. In our sample, the presence of the second glass probably correlates with incorporation (and remelting?) of fragments of an earlier rhyolitic ash or tuff. Two different types of Mexican rainbow obsidian were studied. The first has layers of numerous trachytically oriented rods $(0.2-2$ by $10-20 \mu \mathrm{m})$ of hedenbergite $\left(\mathrm{Ca}_{0.88} \mathrm{Mg}_{0.07} \mathrm{Fe}_{0.98} \mathrm{Mn}_{0.06} \mathrm{Si}_{2.01} \mathrm{O}_{6}\right)$. The composition of the matrix is: 76.3 $\mathrm{SiO}_{2}, 12.5 \mathrm{Al}_{2} \mathrm{O}_{3}, 1.7 \mathrm{FeO}_{\mathrm{TOT}}, 0.01 \mathrm{MgO}, 0.16 \mathrm{CaO}, 4.4 \mathrm{Na}_{2} \mathrm{O}$ and $4.6 \mathrm{~K}_{2} \mathrm{O}$. The second type has trachytically aligned plagioclase $\left(\sim \mathrm{An}_{20}\right)$, also rod-shaped (as small as $\left.0.5 \times 2.0 \mu \mathrm{m}\right)$. The composition of the matrix is: $76.1 \mathrm{SiO}_{2}, 13.5 \mathrm{Al}_{2} \mathrm{O}_{3}, 0.7 \mathrm{FeO}_{\mathrm{TOT}}, 0.09$ $\mathrm{MgO}, 0.7 \mathrm{CaO}, 3.75 \mathrm{Na}_{2} \mathrm{O}$ and $4.85 \mathrm{~K}_{2} \mathrm{O}$. Multiple hypotheses are considered for the possible cause of the rainbow effects: gas or fluid inclusions, a small component of scattering centers, differential indices of refraction, Bragg diffraction of visible light, and thin-film interference. Our data support the last hypothesis.
\end{abstract}

Keywords: obsidian, Mexico, optical properties, rainbow, sheen, thin-film interference colors.

\section{SOMMAIRE}

Nous avons étudié des échantillons d'obsidienne mexicains qui possèdent soit un reflet monochrome ou en arc-en-ciel au moyen d'analyses par microsonde électronique, microscopie électronique à balayage (MEB) et par transmission, et par spectroscopie visible et infra-rouge. Les analyses à la microsonde électronique de la matrice vitreuse où le reflet est monochrome

E-mail addresses: chi@gps.caltech.edu,jgresh@udel.edu, grr@gps.caltech.edu, gulmer@astro.ocis.temple.edu, vicenzi@volcano.si.edu

$\S \quad$ Present name and address: Jennifer Greller, Department of Geology, University of Delaware, Newark, Delaware 19716, U.S.A.

Il Present address: Department of Mineral Sciences, National Museum of Natural History, Smithsonian Institution, Washington, D.C. 20560, U.S.A. 
donnent, en \% pondéraux, 76.2 $\mathrm{SiO}_{2}, 0.2 \mathrm{TiO}_{2}, 11.6 \mathrm{Al}_{2} \mathrm{O}_{3}, 2.2 \mathrm{FeO}_{\mathrm{TOT}}, 0.07 \mathrm{MgO}, 0.1 \mathrm{CaO}, 4.8 \mathrm{Na}_{2} \mathrm{O}$ et $4.4 \mathrm{~K}_{2} \mathrm{O}$. Le reflet serait dû à la présence de microvésicules vides étirées lors d'un flux, selon la littérature gemmologique. Les images obtenues au MEB montrent que les domaines lenticulaires étirés contiennent un deuxième verre, de composition moyenne $(\%) 74.6 \mathrm{SiO}_{2}, 0.2 \mathrm{TiO}_{2}$, $12.7 \mathrm{Al}_{2} \mathrm{O}_{3}, 2.1 \mathrm{FeO}_{\mathrm{TOT}}, 0.1 \mathrm{MgO}, 0.9 \mathrm{CaO}, 5.6 \mathrm{Na}_{2} \mathrm{O}$ et $4.6 \mathrm{~K}_{2} \mathrm{O}$. Ces deux compositions sont distinctes à un écart de $2 \sigma$ près. Leurs indices de réfraction diffèreraient par au moins 0.04 , ce qui pourrait bien mener à une interférence optique le long de l'interface elliptique entre les deux verres. Le reflet monochrome résulterait donc de différences en indices de réfraction $(\eta)$ entre l'obsidienne de la matrice et celle des vésicules, dont l'indice $\eta$ est plus faible. Dans notre échantillon, la présence d'un deuxième verre pourrait bien résulter de l'incorporation (et refusion ?) de fragments d'une cendre rhyolitique ou d'un tuf antérieur. Nous avons aaussi étudié deux sortes d'obsidienne mexicaine à reflets polychromes (en arc-en-ciel). La première contient des trainées de microbâtonnets $\left(0.2-2(10-20 \mu \mathrm{m})\right.$ d'hédenbergite $\left(\mathrm{Ca}_{0.88} \mathrm{Mg}_{0.07} \mathrm{Fe}_{0.98} \mathrm{Mn}_{0.06} \mathrm{Si}_{2.01} \mathrm{O}_{6}\right)$, alignés par flux. La composition de la matrice (\%) est: $76.3 \mathrm{SiO}_{2}, 12.5 \mathrm{Al}_{2} \mathrm{O}_{3}, 1.7 \mathrm{FeO}_{\mathrm{TOT}}, 0.01 \mathrm{MgO}, 0.16 \mathrm{CaO}, 4.4 \mathrm{Na}_{2} \mathrm{O}$ et $4.6 \mathrm{~K}_{2} \mathrm{O}$. Le second type montre un alignement trachytique de plagioclase $\left(\sim \mathrm{An}_{20}\right)$, aussi sous forme de bâtonnets (aussi petits que $\left.0.5 \times 2.0 \mu \mathrm{m}\right)$. La composition de la matrice (\%) est: $76.1 \mathrm{SiO}_{2}, 13.5 \mathrm{Al}_{2} \mathrm{O}_{3}, 0.7 \mathrm{FeO}_{\text {TOT }}, 0.09 \mathrm{MgO}, 0.7 \mathrm{CaO}, 3.75 \mathrm{Na}_{2} \mathrm{O}$ et $4.85 \mathrm{~K}_{2} \mathrm{O}$. Nous évaluons plusieurs hypothèses pour expliquer les effects en arc-en-ciel: inclusions de gaz ou de fluide, une faible proportion de centres de dispersion, des différences en indices de réfraction, une diffraction de la lumière visible selon la loi de Bragg, et une interférence de pellicules très minces. Nos données concordent avec la dernière de ces hypothèses.

(Traduit par la Rédaction)

Mots-clés: obsidienne, Mexique, propriétés optiques, arc-en-ciel, reflet monochrome, couleurs d'interférence de pellicules minces.

\section{INTRODUCTION}

The general interest in the optical properties of both sheen and rainbow types of obsidian has led to passing mention of these in most basic texts of mineralogy and petrology; yet no modern scientific study of these materials could be found in the mineralogical literature. Hence our purpose is to use the textures, chemical compositions and physical properties of sheen and rainbow obsidians to formulate a coherent set of hypotheses that would explain their optical properties. Completely independent studies of rainbow obsidian were conducted at the California Institute of Technology and at Temple University. Preliminary electron-probe data and interpretations were presented by Greller (then Gresh) \& Ulmer (1998) as a poster paper and by Rossman (1998), who used an illustrative example of his work on obsidian in his plenary lecture to the IMA. These earlier works and the ensuing research have been integrated into this manuscript.

\section{BACKGROUND INFORMATION}

Sheen obsidian displays a single-color velvety optical property that is generally characterized by either a silvery or golden hue. This response is directionally dependent and commonly is in both the surface and nearsubsurface of polished obsidian as a grain effect (not unlike wood burls), with both planar and swirled optical features. The optical flash of the sheen is clearly linked to these planar and swirl features. Typically the sheen originates from a single planar zone $\mathrm{mm}$ to $\mathrm{cm}$ in thickness. Areas and volumes between these planes do not show a sheen. An example of golden sheen is shown in the carved obsidian turtle depicted in Figure 1a. The turtle's back and the top of its head appear velvety and golden by comparison to the otherwise normal black obsidian.

Rainbow obsidian, on the other hand, shows bands of various colors, ranging from red through purple. In this study, we establish that there is a correlation of the color bands both with the thickness of and with the location of microphenocrysts within the studied samples. Thus the rainbow material has repetitive closely spaced optical responses at visible wavelengths when viewed on a polished surface or near-subsurface. As shown in the polished pieces depicted in Figures $1 \mathrm{~b}$ to $1 \mathrm{~h}$, coplanar zones that may differ in thickness from $\mathrm{mm}$ to $\mathrm{cm}$ consist of several color bands (for example, red, green, yellow, blue). Note that Figure 1h shows two sides of

FIG. 1. Polished samples of sheen and rainbow obsidian selected to show a range of colors and optical response intensities. a) Turtle carved from golden obsidian. Top of head and shell show golden hue that is generated from an optical effect within and under the surface of the carving. Size: $9 \mathrm{~cm}$ in length. b) Sample selected for unusual colors and large size of individual color bands. Size: $11 \times 6 \times 3 \mathrm{~cm}$. c) Sample with very brilliant, intense blue band. Size: $3 \times 5 \times 2 \mathrm{~cm}$. d) Sample with intense yellow layer. Size: $3 \times 5 \times 4 \mathrm{~cm}$. e) Nodule with intense red layer. Size: $5 \times 5 \times 3.5 \mathrm{~cm}$. f) Heart shape with finely alternating green and blue layers. Size: $4 \times 4 \times 3 \mathrm{~cm}$. g) Elongate heart with noticeably more pastel colors than other samples. Size: $4 \times 7 \times 3 \mathrm{~cm}$. h) Two sides of a broach with highly different colors on the two sides. Size: $7 \times 1 \times 1 \mathrm{~cm}$. Samples b-d have hedenbergite inclusions (Type I), whereas samples $\mathrm{f}-\mathrm{h}$ have feldspar inclusions (Type II). Sample e could not be destroyed, so that no examination of its inclusions could be made. 

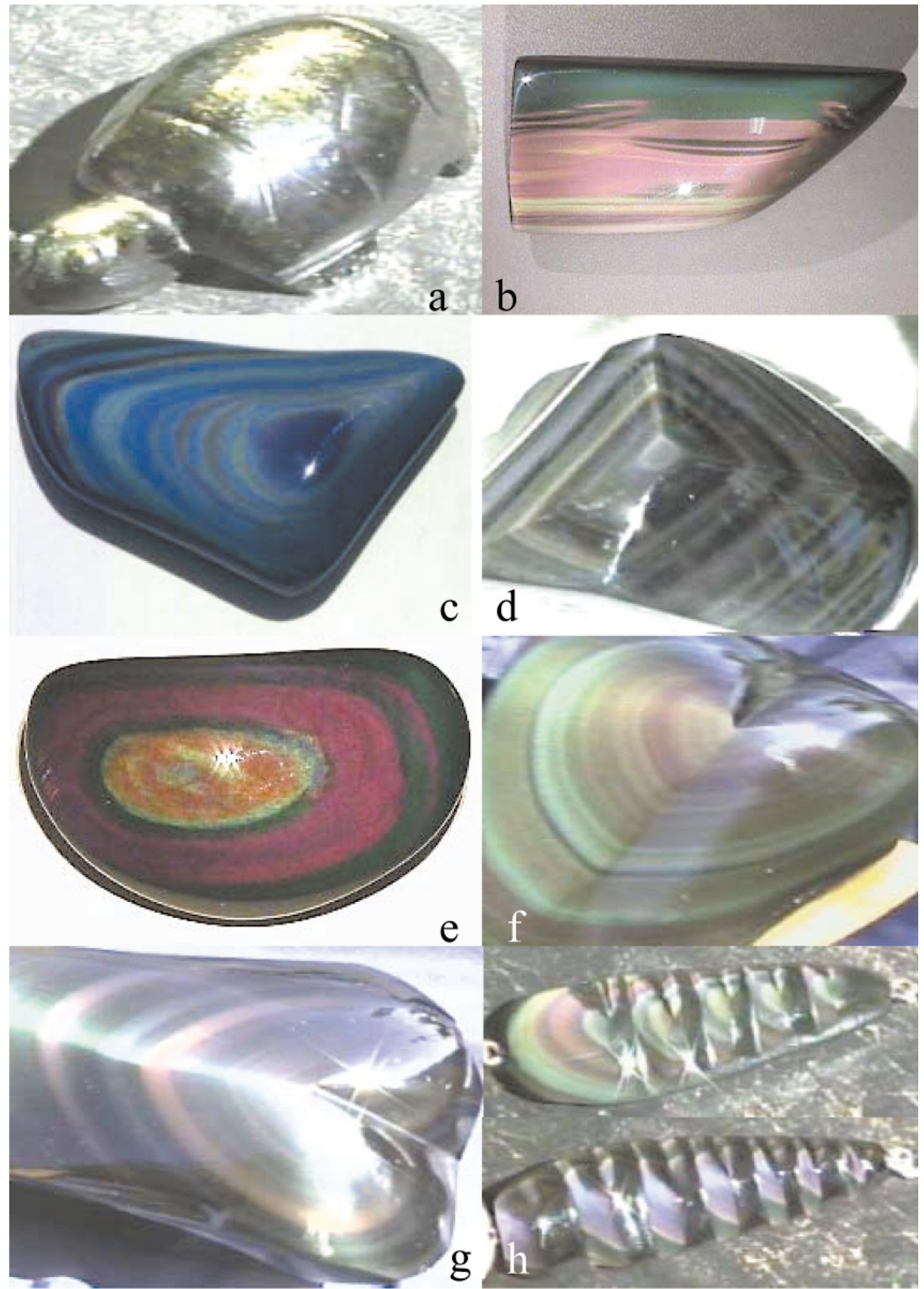
the same necklace piece, cut so as to orient the two surfaces in two different coparallel optic bands of the rainbow effect only about $0.8 \mathrm{~cm}$ apart, but with quite different colors. Rainbow bands may be directly adjacent to, or separated by, "normal" obsidian that shows no special optical effects. Repetition of any color is also possible in coparallel planar zones within a single piece (Figs. 1b, f).

\section{DEFINITIONS}

Published studies of sheen and rainbow obsidians do not offer a rigorous definition of these terms. We equate the term sheen with synonyms such as "flame" or "golden" or "silver" that have found their way into texts (Mitchell 1987). Hurlbut \& Switzer (1979) ascribed this sheen "to reflections from oriented inclusions".

The term rainbow is synonymous with "iridescent" or "color-banded" in the gemological literature (Hadley 1993). Descriptions are vague. Matlins \& Bonanno (1995) ascribed the phenomenon to "a strong internal iridescence", and Foerster (1991) referred to the presence of "microcrystallites".

\section{Provenance of the Samples}

Pieces of obsidian with optical phenomena are often fabricated into "objects of art", as shown in Figure 1. Accordingly, our samples were obtained as shaped and polished pieces. However, it is generally difficult to determine the exact provenance of such specimens.

Of the many archeologically important sites of obsidian in Mexico (Mosheim \& Althaus 1988), or even in the world (Althaus 1996), few localities have been reported that display the sheen or rainbow properties. Obsidian localities in Oregon (Hadley 1993) and northern California (Mitchell 1987) are well documented and mapped. These U.S. localities are interesting in that they provide both sheen and rainbow obsidians in the same geological settings. However, the bulk of the gem obsidian material now distributed globally is from Mexico. The economic importance of these special types of obsidian to the lapidary trade have made the exact Mexican localities purposely, but understandably, shrouded. Some of the dealers who provided our specimens stated that they come from an area near Lago de Moreno, Jalisco, Mexico. Perusal of geological maps seems to indicate no volcanoes near this area. Therefore, we considered it important to attempt to confirm by geochemical fingerprinting the localities of our obsidian samples. Our materials do indeed contain geochemical signatures that are consistent with the values of Mosheim \& Althaus (1988) for the Tequila-Magdelena area in the state of Jalisco, Mexico. Similarly, we consider that the sheen obsidian in our study also to be from Mexico, and the major-element composition are again consistent with this provenance. Figure 2 presents compositional data for many well-known occurrences of obsidian around the world. These data confirm that our samples of obsidian have compositions similar to those published by Mosheim \& Althaus, as well as to the siliceous volcanic compositions reported by Harris \& Carmichael (1984) and Wallace \& Carmichael (1992) for the Jalisco area.

\section{EXPERIMENTAL TECHNIQUES}

\section{Sample preparation}

The optical effects present in both sheen and rainbow obsidian are generated from obvious coplanar bands within the obsidian. Examination of standard thin sections cut either parallel or perpendicular to the optical effects demonstrated that the features generating the optical effect are commonly localized in thin layers.

Samples were prepared in two ways. In the first, small portions of well-oriented samples were fractured and examined in the scanning electron microscope to precisely locate the desired horizon. The main sample was then recut at that precise location. Other samples were simply ground down until the desired layer was intersected. Samples for X-ray micro-analysis and transmitted light microscopy were ground and polished with diamond pastes on flat substrates ("no-knap" cloth). Even with these precautions, some pieces of the obsidian (particularly of the sheen type) polished irregularly and yielded a granular texture on the finished surfaces, with too much topographic relief for good analytical results. These samples required additional polishing with softer abrasives such as $\mathrm{TiO}_{2}$ or $\mathrm{Ce}_{2} \mathrm{O}_{3}$.

\section{Instrumentation at Princeton}

Quantitative X-ray micro-analysis was conducted with a Cameca SX-50 six-spectrometer instrument (five wavelength-dispersion spectrometers + a solid-state Xray detector). Conditions for the analyses included a beam energy of $15 \mathrm{kV}$, a beam current of $15 \mathrm{nA}$, and a defocussed beam $10 \mu \mathrm{m}$ in diameter. The following primary standards were used: $\mathrm{CaSiO}_{3}(\mathrm{CaK} \alpha), \mathrm{KAlSi}_{3} \mathrm{O}_{8}$ $(\mathrm{K} K \alpha, \mathrm{Si} K \alpha$, and $\mathrm{Al} K \alpha), \mathrm{NaAlSi}_{3} \mathrm{O}_{8}(\mathrm{Na} K \alpha), \mathrm{Fe}_{2} \mathrm{O}_{3}$ $(\mathrm{Fe} K \alpha)$, and $\mathrm{TiO}_{2}(\mathrm{Ti} K \alpha)$. Excellent agreement with secondary glass standards (Jarosewich et al. 1980) was obtained (Table 1). Totals close to $100 \mathrm{wt} \%$ indicate that $<0.5 \mathrm{wt} \%$ aggregate of $\mathrm{MnO}, \mathrm{P}_{2} \mathrm{O}_{5}$, and volatile components are present in this material. Qualitative energydispersion spectra (EDS) were collected with a Princeton Gamma Tech digital pulse-processing (PRISM) system of analysis. Secondary electron images were obtained with a Philips FEG XL30 scanning electron microscope (SEM) typically operated at $12 \mathrm{kV}$.

\section{Instrumentation at Caltech}

A Philips 430 transmission electron microscope (TEM) operated at an accelerating voltage of $300 \mathrm{kV}$ was used for bright-field imaging, electron diffraction 


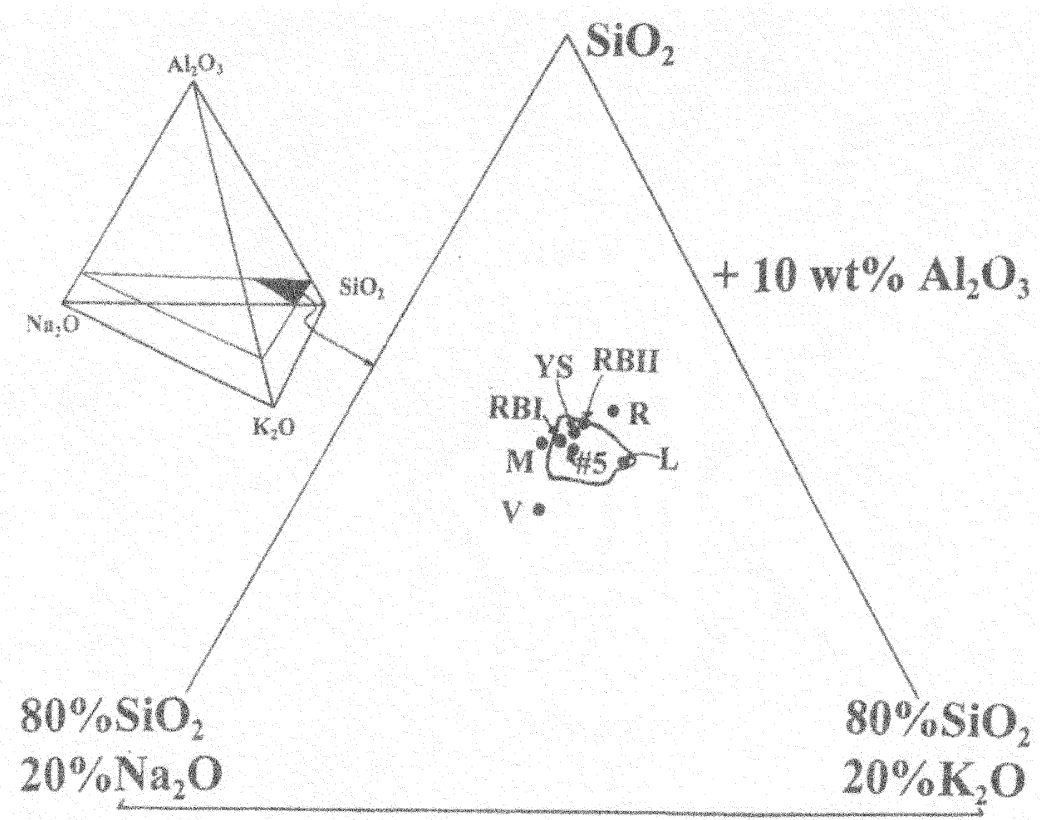

FIG. 2. Compositions of glassy rhyolites and obsidians from world-wide localities. See text for a discussion of the rationale and methodology of projecting into this choice of graphic representation. $L$ represents the average of 40 samples of obsidian from Lipari in the Mediterranean (Althaus 1996). $\mathrm{R}$ is a typical global rhyolite composition (Best 1982). YS represents the Yellowstone rhyolite reported in Table 1. Point \#5 (Mosheim \& Althaus 1988) represents obsidian from Jalisco, Mexico, from the same area as this study. The envelope encloses 14 archeological important samples of obsidian from Mexico, as reported by Mosheim \& Althaus (1988). RB I and RB II pertain to the matrix glass of two types of Mexican rainbow obsidian (Table 1). $\mathrm{M}$ is the matrix composition, and $\mathrm{V}$ is the lenticular glass-filled areas, both in the Mexican sheen obsidian studied here.

TABLE 1. ELECTRON-MICROPROBE DATA FOR SAMPLES OF OBSIDIAN AND TEXTURAL INCLUSIONS

\begin{tabular}{|c|c|c|c|c|c|c|c|c|}
\hline $\mathrm{N}$ & $\begin{array}{c}\text { Sheen } \\
\text { matrix } \\
5\end{array}$ & $\begin{array}{c}\text { Sheen } \\
\text { inclusions } \\
10\end{array}$ & $\begin{array}{c}\text { Rainbow } \\
\text { Type-I } \\
\text { matrix } \\
10\end{array}$ & $\begin{array}{c}\text { Rainbow } \\
\text { Type-I } \\
\text { matrix }^{1} \\
4\end{array}$ & $\begin{array}{c}\text { Rainbow } \\
\text { Type-II } \\
\text { matrix } \\
10\end{array}$ & $\begin{array}{c}\text { Included } \\
\text { phenocrysts } \\
\text { in Type } \mathrm{I}^{2} \\
1\end{array}$ & $\begin{array}{c}\text { USNM } \\
72834 \\
\text { rhyolite } \\
2\end{array}$ & $\begin{array}{c}\text { USNM } \\
2213 \\
\text { syn. tektite } \\
2\end{array}$ \\
\hline $\mathrm{SiO}_{2}$ wt. $\%$ & $76.24(0.21)$ & $74.58(0.37)$ & $76.30(0.27)$ & $77.81(0.23)$ & $76.13(0.43)$ & 48.70 & $76.82[0.11]$ & $76.02[0.27]$ \\
\hline $\mathrm{Al}_{2} \mathrm{O}_{3}$ & $11.57(0.14)$ & $12.67(0.12)$ & $12.45(0.10)$ & $11.83(0.03)$ & $13.48(0.20)$ & 0.00 & $12.39[0.33]$ & $11.49[0.15]$ \\
\hline $\mathrm{CaO}$ & $0.13(0.04)$ & $0.09(0.02)$ & $0.16(0.02)$ & $0.17(0.03)$ & $0.72(0.05)$ & 19.97 & $0.43[-0.07]$ & $2.62[-0.04]$ \\
\hline $\mathrm{MnO}$ & & & & & & 1.78 & & \\
\hline $\mathrm{FeO}$ & $2.19(0.14)$ & $2.09(0.11)$ & $1.72(0.10)$ & $1.68(0.05)$ & $0.70(0.07)$ & 28.45 & $1.11[-0.12]$ & $4.83[-0.06]$ \\
\hline $\mathrm{MgO}$ & $0.07(0.02)$ & $0.06(0.02)$ & $0.01(0.01)$ & 0.00 & $0.09(0.05)$ & 1.09 & $0.03[-0.02]$ & $1.53[0.02]$ \\
\hline $\mathrm{Na}_{2} \mathrm{O}$ & $4.75(0.11)$ & $5.64(0.13)$ & $4.36(0.06)$ & $4.41(0.07)$ & $3.75(0.10)$ & 0.00 & $3.63[-0.12]$ & $1.02[-0.04]$ \\
\hline $\mathrm{K}_{2} \mathrm{O}$ & $4.42(0.09)$ & $4.62(0.08)$ & $4.61(0.07)$ & $4.60(0.04)$ & $4.85(0.07)$ & 0.00 & $4.98[0.09]$ & $1.93[0.05]$ \\
\hline $\mathrm{TiO}_{2}$ & $0.22(0.10)$ & $0.18(0.07)$ & $0.11(0.06)$ & $0.11(0.02)$ & $0.09(0.05)$ & 0.00 & $0.10[-0.02]$ & $0.58[0.08]$ \\
\hline total & 99.59 & 99.93 & 99.72 & 100.61 & 99.81 & 100.00 & 99.49 & 100.02 \\
\hline
\end{tabular}

${ }^{1}$ Electron-microprobe analysis performed at Caltech. ${ }^{2}$ AEM analysis, with results normalized to $100 \%$. Total Fe is expressed as FeO. Values are averages of multiple (i.e., N) analyses. Numbers in parentheses represent one standard deviation of the population (sheen and rainbow obsidians) and brackets, the difference from published values for Smithsonian Institution secondary standards (Jarosewich et al. 1980). 
and analytical electron microscope (AEM) analyses. The specimen for TEM was prepared using an Ar ionbeam mill. A JEOL 733 electron microprobe operated at $15 \mathrm{kV}, 25 \mathrm{nA}$ and utilizing a beam diameter of $10 \mu \mathrm{m}$ was employed for quantitative elemental analysis. Electron back-scattered images were obtained with a CamScan II scanning electron microscope operated at $15 \mathrm{kV}$.

The visible transmission spectrum was obtained on a section of the obsidian $1.1 \mathrm{~mm}$ thick. Reflectance spectra were obtained by focusing ( $f 6,2.5 \mathrm{~mm}$ spot) a tungsten-halogen light source on the surface of a polished piece of obsidian (Fig. 1b) that showed pronounced color bands. The reflected light was collected at a $45 \%$ angle from the incident light. Both experiments used a 1024 element silicon diode array spectrometer. The infrared spectrum of the $1.1 \mathrm{~mm}$ thick section was obtained with a Nicolet 860 FTIR spectrometer using a metal aperture of $1.25 \mathrm{~mm}$ in diameter to define the area of investigation.

An X-ray powder-diffraction pattern of the in situ inclusions was obtained with a Scintag PAD-V diffractometer. The sample was a self-supporting polished slab of the obsidian cut to present the long direction of the inclusions to the X-ray beam.

\section{Graphical Presentation}

In the literature, many different ways of graphically presenting compositions of obsidian and rhyolite have been used. Whereas a plot of CIPW normative compositions projected in the diagram $\mathrm{SiO}_{2}-\mathrm{KAlSi}_{3} \mathrm{O}_{8}-$ $\mathrm{NaAlSi}_{3} \mathrm{O}_{8}$ (petrogeny's residua system) is widely used, we believe that there is a better choice for plotting glass compositions with only a minor proportion of crystalline phases present. In addition, it is clear by inspection of the global reported averages for either rhyolite or obsidian that their $\mathrm{Al}_{2} \mathrm{O}_{3}$ contents range over a very narrow interval, $\sim 10$ to $13 \mathrm{wt} \%$. Accordingly, we have chosen to plot our data on the silica-rich portion of the $10 \mathrm{wt} \% \mathrm{Al}_{2} \mathrm{O}_{3}$ plane of the quaternary system $\mathrm{Al}_{2} \mathrm{O}_{3}-$ $\mathrm{SiO}_{2}-\mathrm{Na}_{2} \mathrm{O}-\mathrm{K}_{2} \mathrm{O}$ (Fig. 2). To project onto this plot, we sum (silica + sodium oxide + potassium oxide as determined by analysis) and normalize to $100 \%$.

Figure 2 shows the tightness of the clustering of the various rhyolitic and obsidian compositions from Mexico. It is credible that our sheen and rainbow samples did all come from Mexico, rather than from other famous localities for obsidian, such as Lipari, in the Aeolian Islands of Italy or Yellowstone, Wyoming.

\section{Results: SHEEN OBSIDIAN}

In the particularly brilliant sheen samples that we examined from Jalisco, Mexico, the matrix obsidian is very uniform in composition (Table 1). The thin and polished thin sections of the sample shown in Figure 1 showed tear-drop and elongate oval areas that are de- cidedly flattened in planar orientations. Originally, we interpreted these to be flow flattened, trachytically aligned, original microvesicles. This interpretation was quickly modified when SEM views revealed three-dimensional lobate fillings and shapes that did not conform geometrically to the inner surface expected from even a distorted gas-filled vesicle. Electron-microprobe analyses of these inclusions show that the glass in-filling of the lenticular areas is both chemically, and therefore likely genetically, distinct from the matrix glass.

Figure 3a shows that the lenticular areas are oriented in planar arrays which, when viewed edge on, produce thin, linear, blade-like features. If viewed perpendicular to the plane of flattening, they appear more obviously oval, with flattened ellipsoidal textural shapes. Figures $3 \mathrm{~b}$ and $3 \mathrm{~d}$ show actual features in transmitted light, respectively, perpendicular and edge-on to the plane of the lenticular features. These features are trachytically aligned from lower left to upper right in each photo. These two photos are taken in oil immersion with slight defocusing to show the population density within the depth of the standard thin section. Figure $3 \mathrm{c}$ is a reflected-light view of another area, but with the same type of sample orientation of the polished section as is present in Figure $3 b$.

Figure $4 \mathrm{a}$ is a secondary electron image showing more details of the unusual morphologies of an individual lenticular area viewed edge-on. Back-scattered electron images in Figures 4b, $4 \mathrm{c}$ and $4 \mathrm{~d}$ are views looking down on the planar array of the lenticularly flattened areas. The images in Figures $4 d$ and $3 c$ do not rule out a simple interpretation of "empty" (formerly gas-filled) microvesicles. However, Figures $4 \mathrm{a}, 4 \mathrm{~b}$ and $4 \mathrm{c}$ show morphological features not easily equated with "empty" vesicles or voids. These observations led to the conclusion that many, but not all, of these features indeed contain a solid filling. The polish on the samples in Figure $4 \mathrm{~b}, 4 \mathrm{c}$ and $4 \mathrm{~d}$ is particularly hackly, despite several attempts to improve it, apparently owing to the plucking out and mechanical damage done by the "roof" fragments of the cracking or separating tops, as polishing plucked open the tops of such lenticular areas.

Examination of Table 1 allows comparison of the matrix obsidian to the glass infilling of many of these features. In general, the infilled lenticular areas are flattened glassy inclusions that are higher in $\mathrm{Al}$ and $\mathrm{Na}$, and lower in $\mathrm{Si}$ and $\mathrm{K}$, than is the matrix obsidian. But these statistically real differences between the glass infilling and the matrix are not so large as to preclude the petrogenetic interpretation that, in addition to gasfilled vesicles, some of these lenticular areas are remelted ash fragments from a previous (or penecontemporaneous ?) rhyolitic eruption that became incorporated into the matrix-producing obsidian flow. That the included fragments are all in flattened lenticular shapes would indicate that the ash fragments were largely remelted as they were trachytically flow-aligned during the flow of the obsidian matrix. 

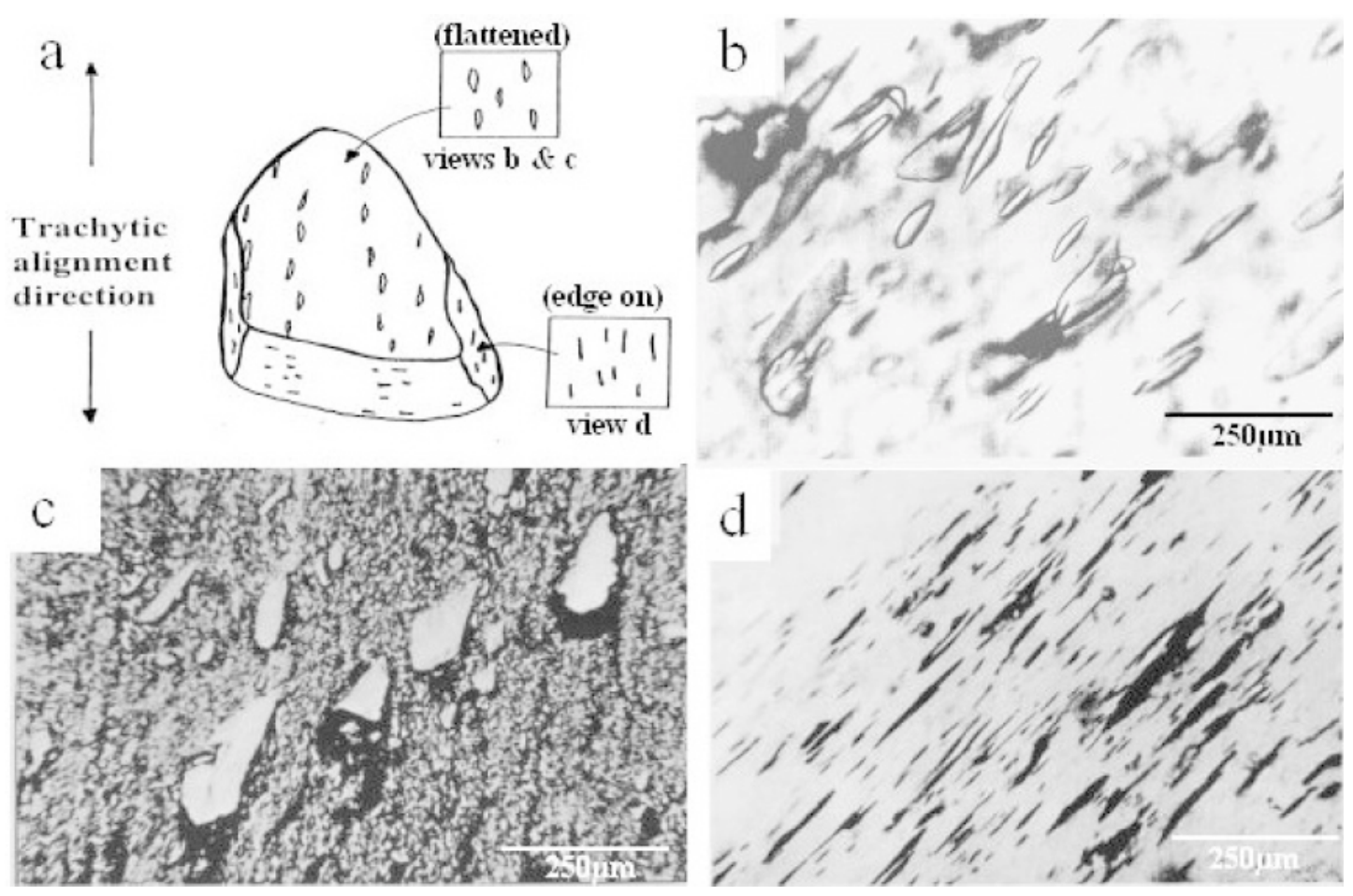

FIG. 3. A composite array of light-microscopy images of the Mexican sheen obsidian studied here. a) Schematic diagram to show the orientation of flattened, gas- and glass-filled lenticular features found within these samples. b) Transmitted light microscopy oriented to be looking down on the plane in which the lenticular areas are flattened. c) Same orientation as view b), but on a polished surface in reflected light. d) Transmitted light microscopy in oil immersion and purposely defocused to show the three-dimensional aspect of the edge-on lenticlar areas. Note they are dark because of light scattering.

\section{RESULTS: RAINBOW OBSIDIAN}

We have discerned two types of rainbow obsidian in the samples from the Tequila-Magdelena area of the state of Jalisco, Mexico. In the covariance plots of Mosheim \& Althaus (1988), for example their Figure 2 (p. 611), for $\mathrm{Na}_{2} \mathrm{O}$ versus $\mathrm{K}_{2} \mathrm{O}$, and in our Figure 2, the obsidian samples of the Tequila-Magdelena area of Jalisco show a tight clustering, into which all our data fall. However, within the cluster there are small differences in composition within any given geographic area. The earlier work on the volcanic rocks of the Tequila area by Harris \& Carmichael (1984) and Wallace \& Carmichael (1992) also shows the same overall similarity, although intraflow differences were noted, as one might expect (in typical Harker variation diagrams) at any given volcano. However, in some of our rainbow samples, the microphenocrysts are hedenbergite (hereinafter, Type I), whereas in other rainbow obsidian samples, the microphenocrysts are sodic feldspar (hereinafter, Type II). These two types are mutually exclusive; only one major type of microphenocryst occurs in each type of obsidian. We employ the term microphenocryst to emphasize our interpretation of these crystallites in the obsidian glasses as subliquidus, presolidification crystals. In either type of rainbow obsidian, the trachytic alignment of these crystallites argues for their origin as microphenocrysts.

\section{Type-I rainbow obsidian}

The samples of rainbow obsidian with hedenbergite microphenocrysts are shown in Figures 1b-e. Photomicrographs of Type-I rainbow obsidian are shown in Figure 5; they are taken from slabs of the obsidian in which the prepared surface is coplanar and within the plane producing the optical effect of a rainbow color band. Figure 5a was obtained in transmitted light (utilizing the same conditions as for Fig. 3d). A trachytic array of very well aligned darker-than-matrix rod-shaped crystallites is apparent as a layer of aligned crystals. In Figure 5b, the crystallites are visible as bright needles in back-scattered electron (BSE) images. However, because only a flat single surface is imaged, the crystallites are more 

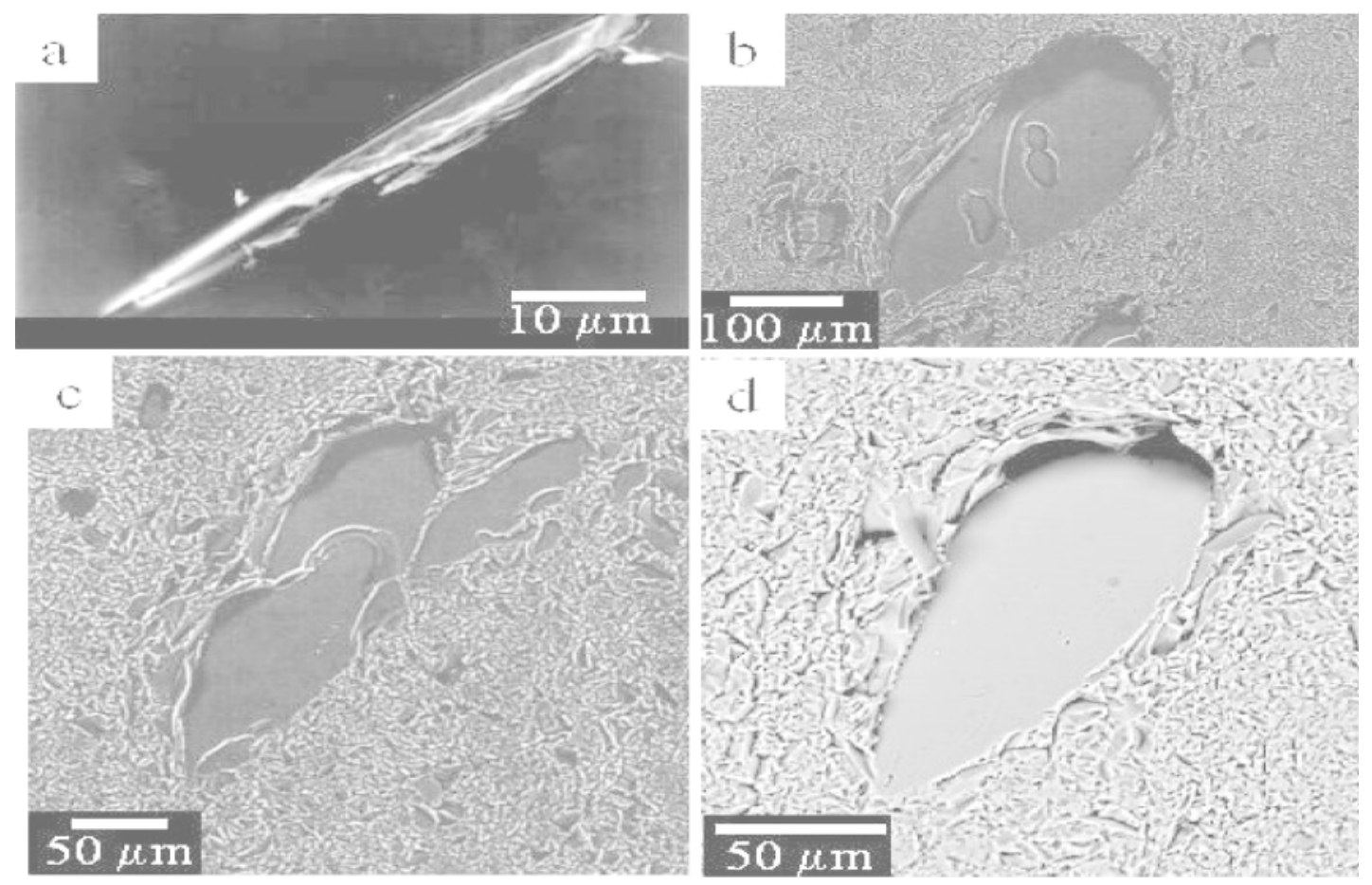

FIG. 4. Electron images of Mexican sheen obsidian. a) Secondary electron image of a single lenticular area seen edge-on in a fractured surface. Note the non-uniform thickness of the infilling material. Photos b) - d) are back-scattered electron images (from the electron microprobe) of lenticular areas looking down onto the plane in which they are flattened. Note that the very flat bottom to feature d) is in strong contrast to features b) and c), with "plateaus" and "mesas" of an infilling material.

sparse than in the defocused, depth-integrating, transmitted light image (Fig. 5a). Even so, the trachytic alignment of crystallites is still clearly evident in the BSE image. TEM bright-field images (Figs. 5c, d) show fine, elongate, prismatic crystals that are oriented nearly parallel to each other. Banding in the obsidian is due to differential abundances of the fine crystals. The dominant population of the rods in the sample studied by TEM ranges from 0.09 to $0.4 \mu \mathrm{m}$ in thickness. A small population of rods 0.8 to $1.2 \mu \mathrm{m}$ thick also was observed. These thicker rods produced interference colors between crossed polarizers in thin section in transmitted light. We have observed that rod sizes may differ in different bands even within the same sample. The integrated examination of many samples (not all depicted here) in the two labs indicates that these samples of rainbow obsidian have microcrystallites with a size covering the range from 0.09 to $2.0 \mu \mathrm{m}$ thick by $10-20 \mu \mathrm{m}$ long.

Analytical TEM measurements of the microcrystallite rods give a mean chemical formula $\mathrm{Ca}_{0.88} \mathrm{Mg}_{0.07}$ $\mathrm{Fe}_{0.98} \mathrm{Si}_{2.01} \mathrm{O}_{6}$, corresponding to hedenbergite. An XRD pattern of the rainbow obsidian shows broad scattering expected from the obsidian glass matrix. In addition, it shows weak lines at $d=3.2 \AA$ (220), $2.96 \AA$ (310), 2.14 $\AA(\overline{4} 21)$, and $1.76 \AA$ (150), all of which correspond to hedenbergite. A peak observed at $d=3.17 \AA$ remains unidentified. A few grains $(2-8 \mu \mathrm{m})$ of opaque oxides (morphology and EDS analysis suggest that most are magnetite, and the remainder are ilmenite) were seen in all samples of the rainbow obsidian, but these are rare in comparison to the large population of the silicate microphenocrysts.

Visible and IR spectral data are presented in Figure 6. The optical transmission spectrum (Fig. 6a) indicates that the light transmitted by the sample steadily increases as the wavelength increases. The only distinct departure from the general trend is a weak absorption band centered at about $800 \mathrm{~nm}$. Figure $6 \mathrm{~b}$ provides a reflectance spectrum (for the sample shown in Fig. 1b) with maxima in reflectance for the green area of the sample at $520 \mathrm{~nm}$ and for the dark red region of the sample near $800 \mathrm{~nm}$. Figure 6c presents infrared spectral data that show a strong $\mathrm{OH}$ absorption band in the $\sim 3600-2600 \mathrm{~cm}^{-1}$ region. These IR spectral data, when combined with the assumed density of the obsidian, 2.33 $\mathrm{g} / \mathrm{cm}^{3}$, and an assumed molar absorption coefficient $(\varepsilon)$ of 88 , indicate a total $\mathrm{H}_{2} \mathrm{O}$ content for the sample of 


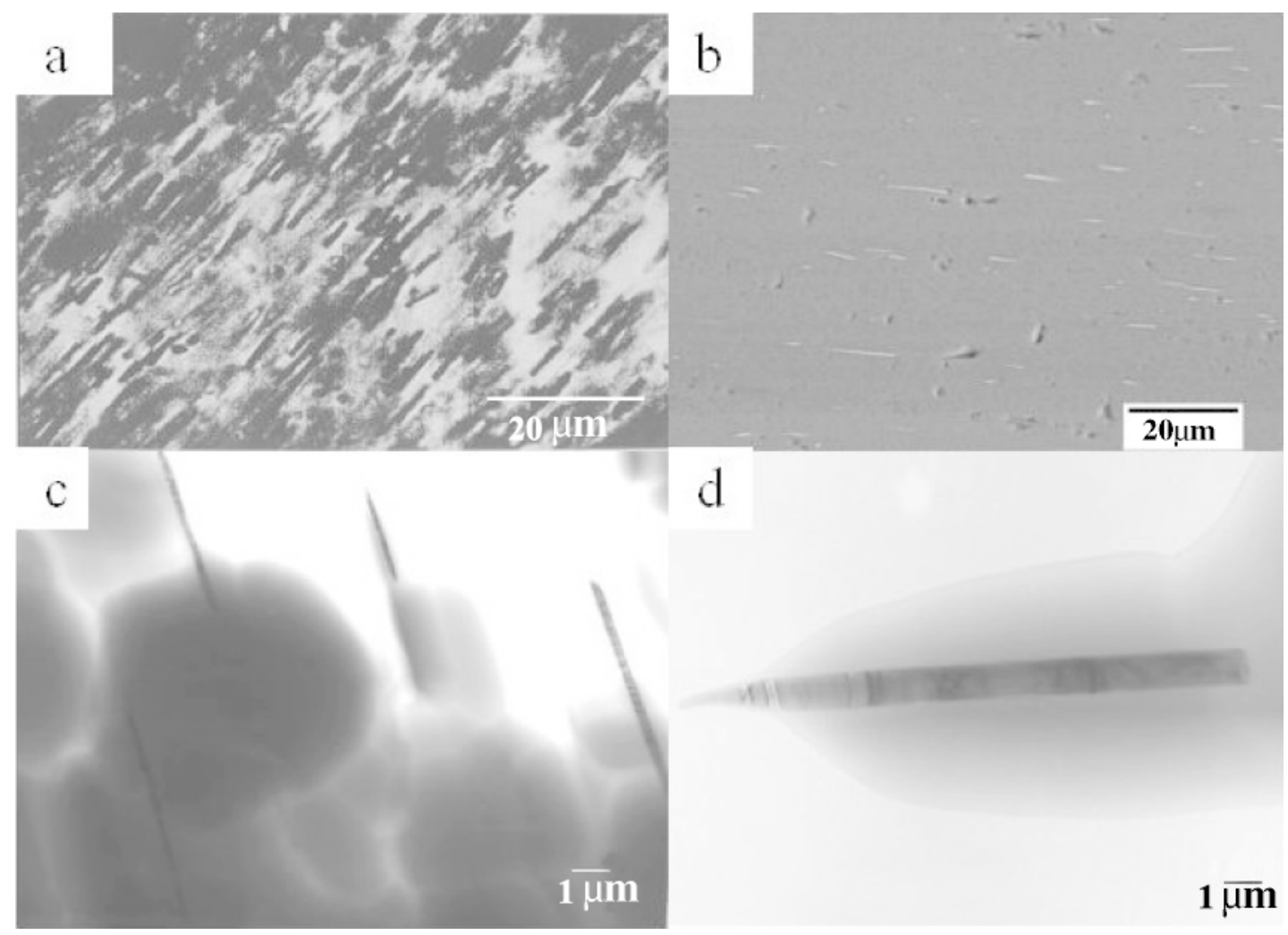

FIG. 5. Optical and TEM images of Type-I rainbow obsidian. a) Transmitted light microscopy with oil-immersion lens purposefully focused in the interior of a standard thin section. The pyroxene rods appear black against the more transparent high-silica matrix. b) Back-scattered electron image of nearly parallel, elongate crystals of hedenbergite. c) TEM bright-field image of hedenbergite crystals in obsidian. d) TEM bright-field image of the details of a single hedenbergite crystal. The vertical bands in the hedenbergite crystal are a combination of thickness fringes and bend contours caused by beam-induced heating. Width of the single rod is about $170 \mathrm{~nm}$. The subtle horizontal bands in the obsidian are thickness contours induced by ion thinning.

$0.095 \mathrm{wt} \%$ according to the procedure of Newman $e t$ al. (1986), as modified by Dobson et al. (1988).

\section{Type-II rainbow obsidian}

The typical macroscopic appearance of polished Mexican rainbow obsidian with feldspathic microphenocrysts is depicted in Figures 1f-h. In Figure 7, transmitted light and scanning electron microspcope images of Type-II rainbow obsidian are shown. In Figures $7 \mathrm{a}$ and $7 \mathrm{c}$, the surface of observation is coplanar and within the plane producing the optic effect of a rainbow color band. Figure 7a was obtained in transmitted light with oil immersion and with slight defocusing within the thickness of a standard thin section. A planar array of trachytically aligned microcrystallites is visible. Figures $7 \mathrm{~b}$ and $7 \mathrm{c}$ are SEM images along a fractured surface and within a polished section, respectively. In
Figure $7 \mathrm{~b}$, the view is edge-on with respect to the planar feature or planar array of crystallites observed, with a high population-density of crystallites striking diagonally (NW-SE) across the image. At higher magnification, Figure $7 \mathrm{c}$ gives a view that is in the plane of the same array as was shown edge-on in Figure 7b. Figure $7 \mathrm{c}$ shows several non-seriate populations of size ranges of crystallites that all are in the same planar array of crystallites. This planar array correlates with an observable rainbow optic effect. All these crystallites were found to be plagioclase whose core is $\mathrm{An}_{20-22}$ and whose rim is $\sim \mathrm{An}_{14}$. The feldspar crystallites commonly show some skeletal growth as well as overgrowths at the polygon corners, texturally suggesting that the $\mathrm{An}_{20}$ microphenocrysts were continuing to crystallize to more sodic compositions as the rhyolitic magma erupted and cooled. The larger crystallites were analyzed, but the smaller crystallites are too small for a quantitative analy- 

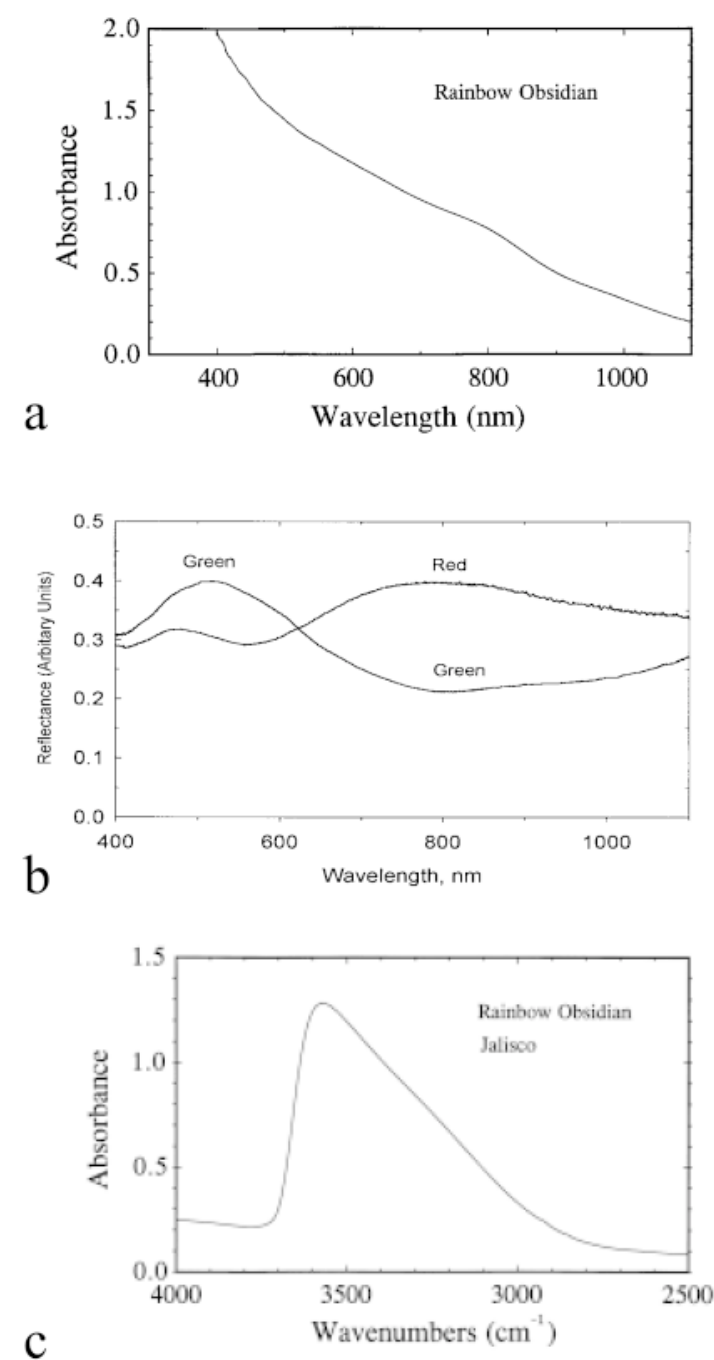

FIG. 6. Spectral data in the visible and IR regions for Type-I rainbow obsidian. a) Optical absorption versus wavelength for a sample slab $1.11 \mathrm{~mm}$ thick, oriented to contain the long axis of the hedenbergite crystals. The spectral trace has been shifted down to keep it on scale; true absorbance at $1100 \mathrm{~nm}$ is 2.17 (absorbance is unitless). b) Reflectance spectra obtained from purple-red and green zones of the rainbow obsidian, Type-I sample shown in Figure 1c. c) The infrared spectrum of the $1.11 \mathrm{~mm}$ thick slab of obsidian.

sis. In elemental X-ray mapping (not shown), all crystallites have a similar composition and zonation. Figure 7 shows that the smallest crystallites are lath-shaped and range in size from 0.2 to $0.8 \mu \mathrm{m}$ wide by 0.2 to $10 \mu \mathrm{m}$ long.

\section{INTERPRETATIONS}

\section{Sheen obsidian}

Dietrich \& Skinner (1979) pointed out that obsidian might have "submicroscopic ...tiny bubble holes, commonly giving a gold colored sheen" (p. 153). However, a detailed optical explanation of why the bubbles cause sheen is not given in this or other standard mineralogical references. Furthermore, we have shown here that Mexican specimens also contain planar arrays of flattened and trachytically oriented, glass-filled lenticular features (Figs. 3, 4).

These gas-filled vesicles or glass-filled areas are stretch-aligned or even flattened by the trachytic alignment during flow. In considering the gas-filled vesicles, the index of refraction of the matrix obsidian (Fig. 8) is higher than the index of refraction of any gas-filled or empty $(\eta \approx 1.0)$ vesicle. A calculation of the critical angle [r] using Snell's Law,

$$
\frac{\eta_{\text {obsidian }}}{\eta_{\text {vesicle }}}=\frac{1}{\sin r}
$$

shows that incident light coming through the obsidian and striking the obsidian/vesicle interface at an angle greater than $43^{\circ}$ (measured from the normal to that interface) would be totally reflected. Thus much of the light striking the outer surface of such vesicles would "mirror" back, and the critical-angle phenomenon would back-scatter much of the incident light. The exact color of the produced "sheen" could be due to many factors that also influence the wavelength of the light transmitted, such as other discrete submicroscopic particles present in the matrix glass. Iron oxide is frequently cited in the literature as a potential cause for the normal dusky optical effect in most obsidian, though we have not observed any abundance of such a phase in our SEM observations.

Our sample shows planar arrays of both empty vesicles and glass-filled lenticular areas. Measurement of the index of refraction of the glass infilling shows that it is higher than the index of the obsidian matrix by as much as 0.04 (Fig. 8, shown by the bold box and adjacent, double-headed arrow). Under these circumstances, the light entering the obsidian would refract into the glass infilling, but would reflect mirror-like from the opposite, back surface of the feature as the light ray proceeds and tries to enter the lower-index matrix on the far side of the glass infilling. According to Snell's Law, the critical angle of refraction in this interface is $75^{\circ}$. We therefore contend that the sheen effect is produced by light scattering within the obsidian wherever the incident ray encounters a decrease in the index of refraction due to an inclusion with either gas or glass infilling. 


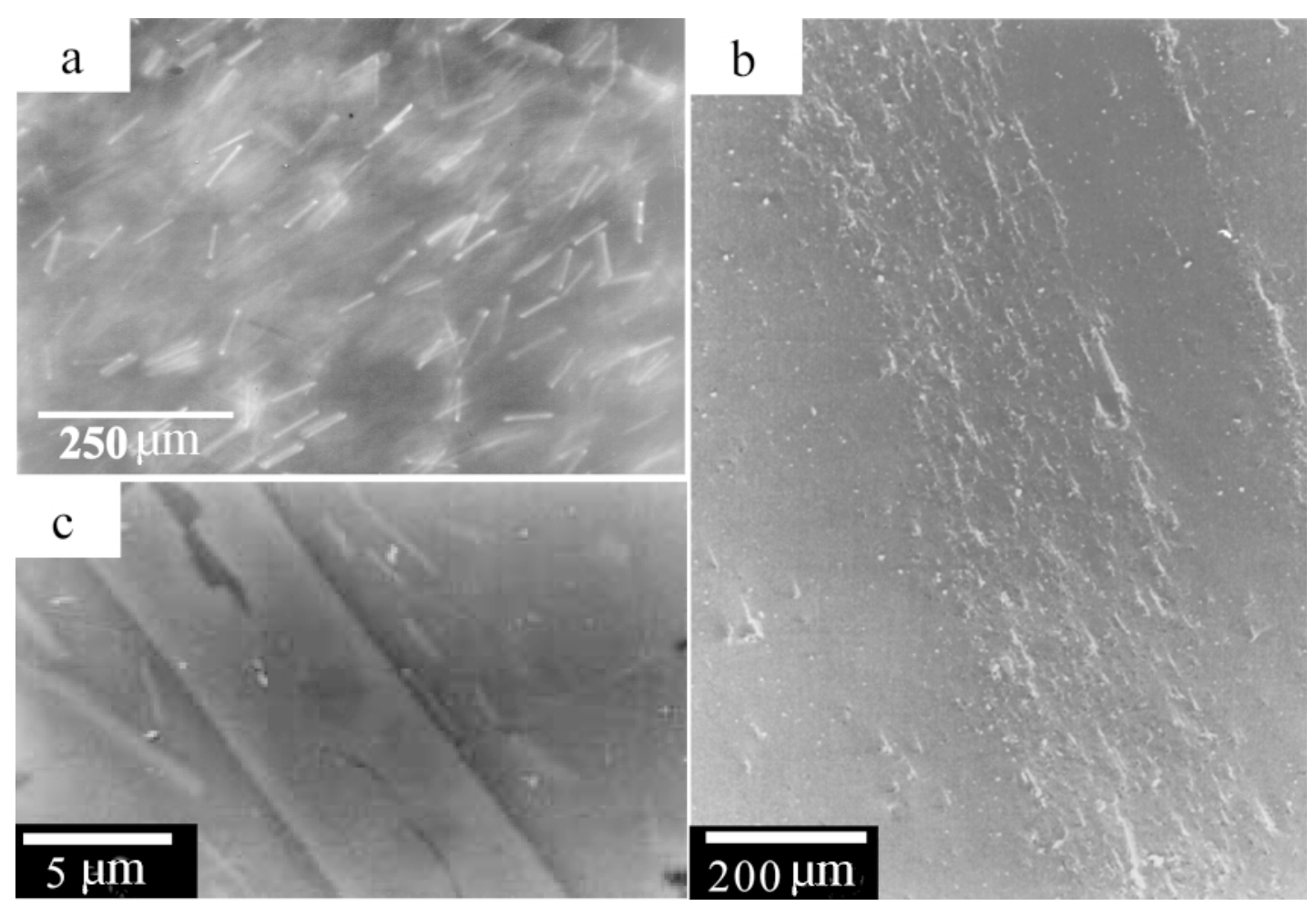

FIG. 7. Images of Type-II rainbow obsidian. a) Transmitted light microscope image taken with an oil-immersion lens purposefully focused in the interior of a standard thin section. The illumination was arranged to show the transparent laths of feldspar. Width of field of view is $1.0 \mathrm{~mm}$. b) Secondary electron image of a fractured surface showing the edge-on view of the aligned crystals striking diagonally (NW-SE) across the image. c) Secondary electron image of the crystals within the aligned plane of image $\mathrm{b}$. This higher-magnification image shows a non-seriate population of crystals, whose thickness ranges from $\sim 5$ to $\sim 0.05 \mu \mathrm{m}$. Note that even the larger crystal is a microphenocryst whose texture (hollow center) suggests rapid growth.

\section{Rainbow obsidian}

Phillips \& Griffen (1981) have stated in their discussion of obsidian that "pyroxene crystallites aligned by flow may polarize light, adding to the dark color or causing a silky surface sheen, or play of colors, which may appear dominantly golden, silvery, greenish or violet" (p. 329). In their statement, they have linked sheen and rainbow to the same effect and do not explain why polarization of the light would produce the myriad effects they otherwise correctly ascribe to various obsidian samples. In addition, in that we have observed rainbow obsidian with only pyroxene in one case, and only feldspar in another, it seems that some clarification of the optical effects of rainbow obsidian is warranted. We consider below a number of hypotheses.

\section{Presence or absence of microvesicles}

No bubbles or fluid inclusions were observed during the investigation of the Mexican rainbow obsidian.
Concentrations of $\mathrm{H}_{2} \mathrm{O}$ are low according to FTIR data (Fig. 6), and the microprobe-derived analytical totals are near $100 \%$, as shown in Table 1. Hence our obsidian is comparatively dry. Thus the rainbow effects are not caused by the presence of bubbles or microvesicles. On the other hand, we have discovered obsidian samples with planar arrays of either clinopyroxene or plagioclase crystals, both of which are completely expected phases in rhyolites [see, for example, CIPW norms in Best (1982), and more recently for hedenbergite, Bindi et al. (1999)].

\section{Absorption band from a component of the obsidian}

The optical transmission spectrum of the obsidian in the visible to infrared region is given as Figure 6a. The gradual increase in transmission from shorter to longer wavelengths is commonly a manifestation of the presence of small centers of scattering in the sample. The weak absorption band at $800 \mathrm{~nm}$ coincides with the $\mathrm{Fe}^{2+}-\mathrm{Fe}^{3+}$ intervalence charge-transfer band in 


\section{Ranges of Refractive Indices}

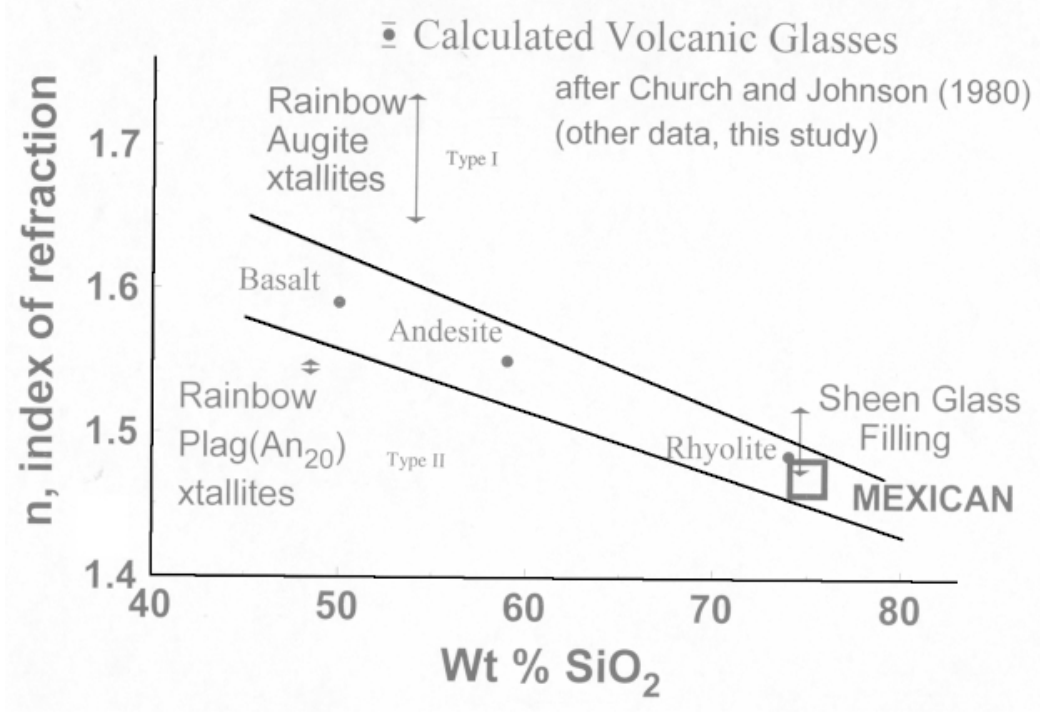

FIG. 8. Summary of index of refraction data for the obsidian samples studied. Straight subhorizontal lines outline the range of indices reported for natural glasses by Church \& Johnson (1980). Round dots show their data for the indicated rock compositions, where found as glasses. The large square symbol represents the cluster of our measurements for the various samples of Mexican obsidian studied. Double-headed vertical arrows represent, as indicated on the graph, the range of indices from the literature for the microphenocrysts found within the obsidian samples of this study.

hedenbergite (Amthauer \& Rossman 1984). Overall, the spectrum confirms the visually apparent observation that the colors do not come from an absorption band of a component of the obsidian.

\section{Evaluation of the indices of refraction}

Our interpretation of the color phenomena in rainbow obsidian began with the proposals of Phillips \& Griffen (1981); in what way are the indices of refraction of the glasses and crystalline phases involved in the optical effect? As depicted in Figure 8, the global averages and ranges of the index of refraction of volcanic glass are reproduced from the work of Church \& Johnson (1980). From the literature, we have also taken the accepted values of the range of indices of refraction of the crystalline phases identified in our investigation. Direct measurements of the indices of refraction of the crystalline phases would have been extremely difficult given their small sizes and the difficulty of separating them from matrix for an index oil technique. When we did attempt some direct measurements of the indices on the matrix glasses with index oils, we did not find any measurements that plotted outside the Church \& Johnson range, shown by the light straight lines in Fig- ure 8. The data plotted in Figure 8 show that for both Type-I and Type-II rainbow obsidians, there is a large differential between the indices of refraction of both types of crystallites and the range in index of refraction for the obsidian matrix. Given that the matrix contains, on average, about $76 \% \mathrm{SiO}_{2}$, the average value of $\eta$ for the matrix of the isotropic Mexican obsidian samples is $\sim 1.47$.

By inspection of Figure 8, one can see that for Type I, the $\delta \eta=\left(\eta_{\text {hedenbergite }}-\eta_{\text {glass }}\right)$ may be as large as 0.27 , whereas for Type II, the $\delta \eta=\left(\eta_{\text {plag }}-\eta_{\text {glass }}\right)$ may be as large as 0.09 . Thus for either type of rainbow obsidian, the passage of light from the obsidian matrix through the crystallite interface would encounter a large increase in the index of refraction at the interface. However the application of Snell's Law here with the anisotropy of the silicate crystallites would lead one to believe that with three different indices for the three crystallographic directions for both clinopyroxene or feldspar, the ray paths would be much more complicated. These differences in index between the obsidian and either type of anisotropic crystallites will thus cause any ray of light entering from the obsidian in a path perpendicular to the glass-crystallites interface to be strongly refracted in the three crystallographic directions of the crystal- 
lites and hence be scattered. Thus the historically proposed inference that properties of refraction provide the explanation(s) of the rainbow optical effect, in our opinion, is not warranted even though the involved $\delta \eta$ values in sheen obsidian and its second phase are responsible for the sheen optical effects.

\section{Possibilities of a diffraction grating}

The sample image in Figure $5 \mathrm{c}$ has hedenbergite rods $7 \mu \mathrm{m}$ apart; if the spacing were extended over larger dimensions, this spacing would correspond to a diffraction grating with 143 grooves per mm. Commercial gratings with 150 grooves per mm make efficient, lowresolution gratings for the wavelengths of visible light. Thus, a diffraction grating origin of the rainbow colors must be considered.

Theoretically, if the crystallites in rainbow obsidian are of the right thickness or spacing (or both), they may cause a coherent diffraction of the entering light. Treating rainbow obsidian in a way similar as did Darragh et al. (1976) for opal, one may utilize a form of the Bragg Law:

$$
\mathrm{n} \lambda=\eta 2 \mathrm{~d} \sin \theta
$$

where $\mathrm{n}$ is the order of the diffraction, $\lambda$ is the wavelength of any light that will diffract, $\eta$ is the index of refraction of the matrix, $d$ is the effective thickness or spacing of the crystallite involved in any color optical effect produced, and $\theta$ is the angle of the ray of incident light arriving.

Again as Darragh et al. (1976) did in explaining the spectral optical effects in opal, one can assume that only the brightest colors are of interest, so that $n$, at least initially, is set at a value of unity (one); $\lambda$ can be chosen in the range of the visible spectra, as we are interested in the colors of the observed rainbow effect; $\eta$ should be taken as the index of refraction of the matrix obsidian (1.47) because that is the medium in which the diffraction is occurring, and $\theta$ can be assumed to be close to $90^{\circ}$ for the viewing of a polished surface that shows the rainbow effect. Thus the Bragg Law simplifies to $\lambda=$ $1.47 \times 2 \mathrm{~d}=2.94 \mathrm{~d}$. Therefore for a red optical effect in which the $\lambda$ of the red is assumed to be $0.700 \mu \mathrm{m}$, the thickness of the crystallite or spacing that may cause such a diffraction would be $0.700 / 2.94=0.238 \mu \mathrm{m}$. Similarly, for a color effect in the blue region of the optical spectra, if one assumes that $\lambda$ is $0.300 \mu \mathrm{m}$, then the thickness of the crystallite, or intercrystalline spacing, that may cause the diffraction would be $0.300 / 2.94$ $=0.102 \mu \mathrm{m}$.

The images in Figures 5 and 7 indicate that even the smallest crystallites are generally larger by more than an order of magnitude than the Bragg-Law-calculated values for both Type-I and Type-II rainbow obsidians. One may alternatively question if the rainbow effects are second-order $(n=2)$ pastel colors. In general, the feldspar-activated rainbow obsidian does seem to have just as intense, but more pastel colors, than the hedenbergite-containing obsidian ( $c f$. Figs. 1b-e with hedenbergite to Figs. 1f-h with feldspar). But even combining these two alternative assumptions, the BraggLaw-calculated crystallite thickness or intercrystalline spacing is only as large as $1.088 \mu \mathrm{m}$ (where: $\lambda=$ blue light, $\mathrm{n}=2$, and $\sin 30^{\circ}$ ). Thus the features needed for theoretically calculated diffraction under all these assumptions range from 0.102 to $1.088 \mu \mathrm{m}$, dimensions that do fall within the measured range reported earlier in this manuscript.

However, one may validly question the appropriate value used for the viewing angle; although it is important to the observation of rainbow effects, it may be as low as $30^{\circ}(\sin 30=0.50)$ without totally "quenching" the intensity or significantly changing the color of the entire optical response. Thus, the viewer's orientation will change the intensity of the rainbow effect, but the color response (wavelength) from rainbow obsidian is not changed to any considerable degree, even over a change in angle of view of $90^{\circ}$. This is in sharp contrast to a ruled diffraction grating, for which a rotation of the grating by a few degrees will change the wavelength of the diffracted light by a sizeable amount, i.e., the socalled observed "play of colors" from diffraction gratings. Thus despite the potential agreement in the size of particles with a diffraction hypothesis, other hypotheses must be examined.

\section{Effects due to thin-film interference}

The argument for thin-film interference effects from the individual microphenocrysts is supported by the overall shape of the optical reflectance profile (Fig. 6b). The spectra not only show that the colored regions of the sample reflect light with maximum efficiency in the appropriate wavelength regions, but also show an oscillatory intensity with a shorter period at shorter wavelengths, a feature consistent with interference colors.

Calculations of interference color reveal that the thickness of the rods is appropriate for the rainbow effects. Thin films a few tenths of a $\mu \mathrm{m}$ thick have firstorder interference colors for the visible wavelengths. Specifically, using the two maxima at 480 and $790 \mathrm{~nm}$ from the reflectance pattern for the red sample (Fig. 6b) and an average index of refraction for hedenbergite, a crystal of hedenbergite of about $350 \mathrm{~nm}$ in thickness would cause the red interference color as indicated by the equations of Smith \& Miller (1944). The green interference would come from objects with a thickness of about $240 \mathrm{~nm}$. These results are generally consistent with the thickness of the hedenbergite crystals observed in the TEM observations (Fig. 5), which were taken in a region with dominantly blue to green color, recognizing that one cannot be totally certain of the colors that the particular rods imaged would cause. 
Similar reflectance spectra for the plagioclase rainbow obsidian have not been as easy to collect. The available width of bands in the hedenbergite sample (Fig. 1b) allowed a $2.5 \mathrm{~mm}$ focused light beam to be entirely within a given color band. Inspection of dozens of pieces of plagioclase-containing rainbow obsidian failed to produce such a thick color band (see Figs.1f-h), and as already noted, the samples of Type-II rainbow obsidian seem to be show only second-order colors. Furthermore, from the data presented here, the laths observed (Fig. 7c) have a thickness in the range from 5000 to $50 \mathrm{~nm}$, but with three non-seriate populations that have median values respectively of $\sim 5000 \mathrm{~nm}, \sim 1000 \mathrm{~nm}$ and $\sim 500$ $\mathrm{nm}$. Since the rainbow effect is present, one may also attempt to validly apply the equations of Smith \& Miller (1944). But to do so, one must adjust for the indices of refraction of plagioclase, and one must assume that the reflectance spectra and fringes are about the same for the second-order, more pastel appearance of the plagioclase-activated obsidian. Taking these assumptions, the red rainbow plagioclase-bearing obsidian would be generated by a crystallite thickness of about $410 \mathrm{~nm}$, and the green plagioclase-bearing rainbow obsidian would be generated by a crystallite thickness of about $275 \mathrm{~nm}$. Under these assumptions, at least one could suspect that the larger two sizes of the populations of plagioclase laths present do not relate to the rainbow effects. The smallest hedenbergite and the smallest plagioclase microcrystallites are certainly in the proper size-range to cause the rainbow effect.

\section{Other General Considerations and Conclusions}

The nomenclature distinction between Type-I (clinopyroxene) and Type-II (feldspar) rainbow obsidian provides a "short", convenient terminology, but is not related, we wish to stress, to a real difference in mechanism in the optical properties of the rainbow obsidian. Furthermore, the apparent paucity of either clinopyroxene or feldspar crystallites in the polished surfaces depicted in Figures $5 \mathrm{~b}$ and $7 \mathrm{c}$ should be understood as being due to a single horizon through a larger volume containing many more trachytically aligned crystallites. This fact is much more apparent in the defocused, depth-integrated transmitted light images (Figs. 5a, 7a), and also is very apparent in the edge-on view of the plagioclase rods (Fig. 7b). Table 1 does show that the matrix obsidian for Type-I and -II rainbow obsidians are remarkably similar in $\mathrm{SiO}_{2}$ and $\mathrm{K}_{2} \mathrm{O}$, but are not the same, even within $95 \%$ confidence, for other oxide components. Nevertheless, the matrix glasses of the two obsidians are sufficiently similar to have nearly the same index of refraction. Consequently, we conclude that the explanation of the two types of rainbow obsidian is not related to the matrix chemistry per se. However, the $\delta \eta$ values between matrix and crystallites for either type of obsidian result in white light being mostly scattered. This fact probably helps to intensify the rainbow effect in that all other light of "improper" wavelength is refracted and scattered, thereby leaving the single "correct" wavelength as the surviving, emerging coherent optical effect generated by the presence of the array of crystallites.

Thus we hypothesize that the arrays of crystallites serve to produce thin-film interference effects and that the composition of the crystallites is not of first-order importance. Rather, it is their size and their spacing that control the observed rainbow effect. The distribution and coherency of the crystals may be spatially varied even in the plane of the rainbow effect, thereby explaining the observation that even within a given piece of obsidian, a given color plane may be more brilliant at one place on the plane than at others. Furthermore, the optimum size of crystal is never quite realized within the obsidian. Note again, for example, the non-seriate sizing of feldspars in Figure 7c. Also, a given colored layer may be repeated, as is observed, because more than once in the given piece, the trachytic flow alignment reaches a given set of optically capable thin-film characteristics.

\section{ACKNOWLEDGEMENTS}

The authors are grateful to the following dealers for their assistance in the procurement of samples and in their attempts to help determine the provenances of the samples: Mr. H. Siegel of Aurora Mineral Corp., Freeport, New York; Mr. M. Belski of Howards Minerals, Brooklyn, New York; Mr. and Mrs. Bey of Beys Minerals, Bartow, Pennsylvania; Mr. L. Castle of Carved Opal and Obsidian, Madison, Wisconsin; Rock $\mathrm{H}$. Currier of Jewel Tunnel Imports, California, and Mike New of Top Stones, Tucson, Arizona. Some of the pieces photographed by the authors were provided through the kindness Bob Gilman, Sr. and Jr. of Lost River Caverns Rock Shop of Hellertown, Pennsylvania. We acknowledge the Princeton Center for Complex Materials grant DMR 94-00362 (EPV) and the White Rose Foundation (GRR) for their support. For his computer manipulation and management of the more than 50 megabytes of images and data in the text file, the authors thank Mr. Mark Manna of Temple University. We thank John B. Brady and an anonymous reviewer for valuable comments.

\section{REFERENCES}

Althaus, E. (1996): Obsidian: Rohstoff-Werkstoff-Handelsgut. Eine Naturmaterial-Industrie in der Frühgeschichte. Chem. Erde 56, 285-312.

Amthauer, G. \& Rossman, G.R. (1984): Mixed valence of iron in minerals with cation clusters. Phys. Chem. Minerals 11, 37-51. 
Best, M. (1982): Igneous and Metamorphic Petrology, W.H. Freeman, New York, N.Y.

Bindi, L., Cellai, D., Melluso, L., Conticelli, S., Morra, V. \& Menchetti, S. (1999): Crystal chemistry of clinopyroxene from alkaline undersaturated rocks of the Monte Vulture volcano, Italy. Lithos 46, 259-274.

Church, B.N. \& Johnson, W.M. (1980): Calculation of the refractive index of silicate glasses from chemical composition. Geol. Soc. Am., Bull. 91, 619-625.

Darragh, P.J., Gaskin, A.J. \& Sanders, J.V. (1976): Opals. Scientific American 234, 84-95.

DIETRICH, R.V. \& SKINNER, B.J. (1979): Rocks and Minerals. John Wiley and Sons, New York, N.Y.

Dobson, P.F., Epstein, S. \& StolPer, E.M. (1988): Hydrogen isotope fractionation between coexisting vapor and silicate glasses and melts at low pressure. Geochim. Cosmochim. Acta 53, 2723-2730.

FoERSTER, R.V. (1991): Not just a black stone. Lapidary J. 45, 63-68, 70 .

Greller, J.L. \& Ulmer, G.C. (1998): Sheen and "rainbow" obsidians: an electron microprobe study. Geol. Soc. Am., Abstr. Programs 30(1), 51.

Hadley, W. (1993): Rainbow obsidian. Rock and Gem 23, 5253.

Harris, J.M. \& CARMichael, I.S.E. (1984): Siliceous volcanics around volcano Tequila, Jalisco, Mexico. Geol. Soc. Am. Bull., Abstr. Programs 16, 530.

Hurlbut, C.S., JR. \& Switzer, G.S. (1979): Gemology. John Wiley and Sons, New York, N.Y.
Jarosewich, E., Nelen, J.A. \& Norberg, J.A. (1980): Reference samples for electron microprobe analysis. Geostandards Newsletter 4, 43-47.

Matlins, A.L. \& Bonanno, A.C. (1995): Jewelry and Gems: the Buying Guide. Gemstone Press, Woodstock, Vermont.

Mitchell, J.R. (1987): Field trip: gem obsidian and banded rhyolite. Rock and Gem 17, 64-67.

Mosheim, E. \& Althaus, E. (1988): Investigacciones quimicas y opticas de obsidianas geologicas y arqueologicas de Mexico. Geofisica Internacional 27, 605-640.

Newman, S., Stolper, E.M. \& Epstein, S. (1986): Measurement of water in rhyolitic glasses: calibration of an infrared spectroscopic technique. Am. Mineral. 71, 1527-1541.

PhILLIPS, W.R. \& GRIFFEN, D.T. (1981): Optical Mineralogy: the Non-Opaque Minerals. W.H. Freeman and Co., San Francisco, California.

Rossman, G.R. (1998): What we have learned about color in minerals. Int. Mineral. Assoc., $17^{\text {th }}$ Gen. Meeting (Toronto), Abstr. Programme, A1.

SMith, D.C. \& MiLLER, E.C. (1944): Infra-red absorption cells and measurements of cell thickness. J. Opt. Soc. Am. 34, $130-134$.

Wallace, P. \& CARmichael, I.S.E. (1992): Alkaline and subalkaline lavas near Los Volcanoes, Jalisco, Mexico: geochemical diversity and its significance in volcanic arcs. Contrib. Mineral. Petrol. 111, 423-439.

Received May 23, 2000, revised manuscript accepted December 28, 2000. 
